at operation, rather than rely on spontaneous leakage (if this ever occurs) or absorption in the few days immediately following operation.

A view of the fundus on the day after operation bears out this supposition in most cases, and in some it would be difficult to tell, except for the area of coagulation, that there had been a detachment present at all, owing to the entire absence of folds or "ripples" in the retina.

Another possible result of leaving residual fluid behind, even when the coagulated area is flat, is the "floating up" of this area of retina by some unavoidable change of position of the patient's head in the 48 hours immediately after operation.

My thanks are due to those honorary surgeons whose patients I have treated by this technique and to Dr. Browning for his helpful interest. The instrument was made for me by Messrs. John Bell and Croyden.

\title{
A HYDROSTATIC APPROACH TO THE POSTERIOR CHAMBER FOR DIAGNOSTIC AND THERAPEUTIC PURPOSES
}

\author{
BY \\ Professor Dr. A. MOTEGI
}

TAIHOKU, JAPAN

IN my clinic there are three types of patients, whose examination and treatment present considerable difficulty.

1. Patients with poor vision where the anterior segment of the eye is nearly normal, but the fundus invisible.

2. Patients with poor vision, following diseases of the anterior segment, peculiar to the tropics, where the fundus is again invisible. In both types of patients a view of the fundus would be of great value.

3. Panophthalmitis, a relatively common condition in my experience and one for which it is rarely possible to do anything.

To deal with these cases I have devised a technique I described as " Intra-ocular irrigation." 'Through an incised wound of the eyeball I run 0.9 per cent. salt solution or Ringer's solution at body temperature.

The excess drops out of the wound. In infected cases this may be followed by autoserum. If the vitreous is fluid, the eye tends to collapse as it exudes. The irrigation restores the globular form of the eye and enables observation of the interior to be made 
through the incision. If the vitreous is turbid it is easier to see the fundus through the clear saline, which replaces it, than through the hazy medium. This method allows both of the removal of the foreign bodies and the lavage from the posterior chamber of infective material in cases of panophthalmitis with possibility of cure under direct vision.

Experimental Evidence.-In order to determine whether a limbal or a scleral section caused the greater trauma and to determine the optimum of the solution and technique, we experimented with rabbits.

We ascertained that while haemorrhage is relatively slight from a penetrating incision of the normal sclerotic, it may be very severe if there are pathological changes in the interior of the eye. We experimented with a diathermy knife, because after incision with a usual knife a haemorrhage occurring during the irrigation rendered observation of the fundus difficult and we ran the risk of detachment and delayed intra-ocular haemorrhage after the operation. Prior to using the diathermy knife, it is advisable to incise the conjunctiva and to resect the ocular muscles to obtain an adequate exposure. Haemorrhage is slight during the use of the electric knife, and if it does occur is easily controlled by coagulation. The main disadvantage, however, is that the wound heals two or three times more slowly than if made with a cutting edge.

We expect perfect healing of a sclero-corneal flap involving $3 / 5$ of the whole corneal edge without keratitis. In rabbits, however, it is advisable to stitch the conjunctival and corneal flaps.

Autogenous in jection of blood into the vitreous space may cause changes in the intra-ocular tissues and is not desirable. I prefer to pass round a Graefe's knife through the centre of the cornea and that of the pupil without touching the retina and ciliary body and to suture a corneo-conjunctival flap.

Contrasting with the normal eyeball we experimented with the intra-ocular irrigation in pathological cases. Of course histological changes at the point of incision were observed after intraocular irrigation, but without cellular infiltration into the retina and choroid.

I experimented with 0.9 per cent. salt solution or Ringer's solution at $12-38^{\circ} \mathrm{C}$, at different pressures between the highest, 10 c.m. of water and the lowest, such as that at which the solution drops through a small cannula.

Technique.-I have paid great attention to the cannula, which is introduced into the vitreous space in this operation.

It is $36 \mathrm{~mm}$. long and its inside diameter $1.5 \mathrm{~mm}$. It must be as thin as possible, so that the introduction can be effected through a small incision. It is made of glass to ensure its visibility, the 
reflex enabling its position to be determined and the retina avoided during operation. The opening at the narrow end of this cannula is so devised that the stream of the solution just turns at an angle to the wound, when it is introduced into the vitreous space,

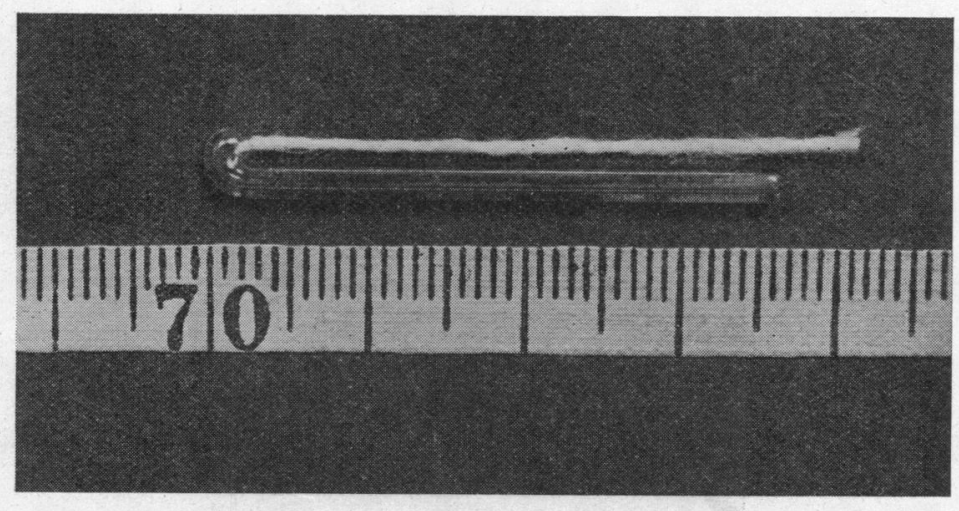

FIG. 1.

Cannula. (The size and direction of the stream of solution is reproduced by a strand of cotton wool).

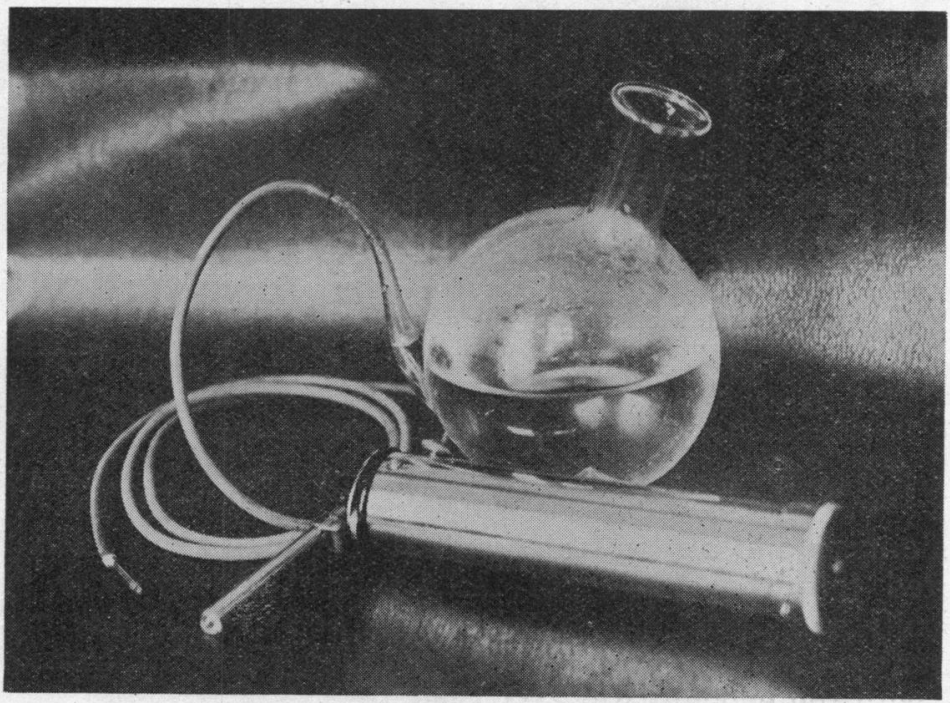

FIG. 2.

Simple equipment for intra-ocular irrigation (an undine with rubber tubing, cannula and electric light). 
thus avoiding pressure on the intra-ocular tissues as much as possible.

The intra-ocular irrigation can be performed by attaching the cannula by rubber tubing to an undine, as shown in Fig. 2, but the equipment actually used by me is shown in Figs. 3 and 4 .

A cylinder contains an electric bulb in the lower half to warm a bottle containing the solution placed in the upper half. A

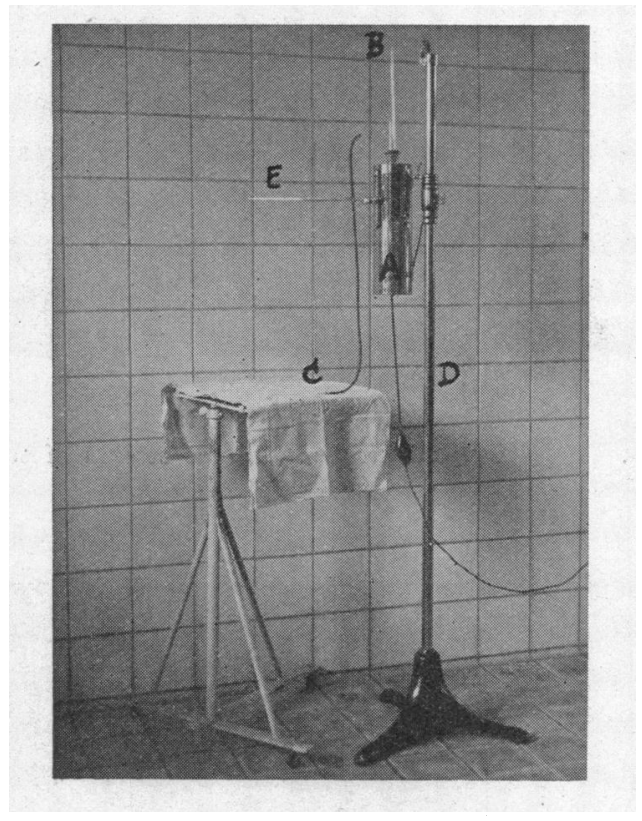

FIG. 3.

Complete set for intra-ocular irrigation. (A) tube; (B) thermometer; (C) cannula; (D) pillar, on which the cylinder can be raised and lowered by a pulley and then fixed by a screw; (E) a pointer to establish the difference in the height of the eye and upper level of the solution.

thermometer and a glass tube with rubber tube and a cannula is inserted into the stopper of the bottle. The cylinder moves vertically supported by a metal upright and fixed by a screw. A pointer is arranged level with the solution horizontally and also level with the eyeball (Fig. 3).

The tube is fixed a little higher (less than $50 \mathrm{~mm}$.) to the pillar with a screw. The pointer is then placed vertically as Fig. 4. 
Finally, one introduces the cannula into the eyeball through the incision. A large corneo-conjunctival flap is made usually in an upward direction involving $2 / 5-3 / 5$ of the whole corneal edge with a large iridectomy as for glaucoma. While the actual irrigation is proceeding one can examine the interior of the eyeball in all directions through the wound with the naked eye and a small but powerful electric light, or remove discharge, pus and foreign

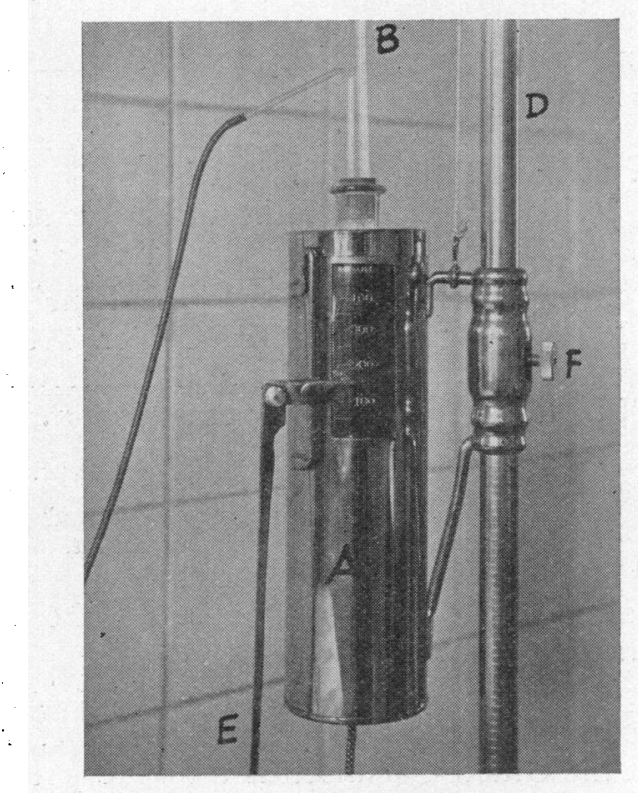

Fig. 4.

Tube (A) with a pillar (D). (B) thermometer;

(E) pointer with a joint; (F) screw for the tube.

bodies under direct vision. Also oblique focal illumination is carried out through the wound, which is held open by the pressure in the vitreous space behind it which is filled by the solution. If this opening is not adequate, it is possible to open the wound further by pulling on one edge with iris forceps.

The cannula with rubber tubing and a glass tube, bottle to contain the solution and thermometer must be sterilised in boiling water.

Review of the Literature.-There is but little literature available on lavage of the hyaloid space. Sterilisation has been attempted in one case of panophthalmitis with $\mathrm{H}_{2} \mathrm{O}_{2}$. I was interested to 
find that $T$. Tutui recently has cured a panophthalmitis case by lavage of the vitreous space with livanol.

According to Grunér, vision of $0 \cdot 1-0 \cdot 5$ was retained in $4 / 20$ panophthalmitis cases by the aid of iodoform. The vitreous space was only locally infected in these cases.

Prof. Dr. J. Komoto has introduced lavage of the hyaloid space for haemorrhage. S. Miyashita, K. Nakamura, T. Masuda and others have called "washing of the vitreous" a process of evacuating part of the turbid vitreous and replacing it by normal salt solution.

I could not find in the literature any similar procedure designed for observation of the interior of the vitreous space as a diagnostic measure prior to treatment of poor visual acuity, removal of foreign bodies, or relief of panophthalmitis. I wish to stress that in my technique the solution drops out of the wound under very slight pressure so as not to obstruct the retina and choroid as it flows.

Literature regarding the length of the limbal incision has been noted by Truc (1904), Matsumoto (1905), Cellier (1908), Wahlfore (1911), and in the works of other authors the anterior segment of the eye is cut off instead of performing enucleation.

Sawaljew (1925) transplanted the anterior segment of the eye 15 minutes after the death of an old woman to a patient with total leucoma.

The segment consisted of cornea, iris, ciliary body and sclerotic, and 4 sutures were inserted. The wound healed completely and the cornea remained clear for a time, but phthisis bulbi finally occurred.

In 1928, Batalin reported transplantation of the whole cornea from one patient to another.

The following references are found to scleral incision in the literature. Elschnig has little to say on this subject in the section on operations in the Graefe-Saemisch Handbook (second and third edition, 1922).

Koch (1927) made a window 3-5 mm. wide and 10-15 mm. long to expose the uvea and to remove a subretinal hydatid worm.

Kreuzfeld (1931) scarified the sclerotic in sympathetic ophthalmitis.

As in my method of intra-ocular irrigation, prognosis is rendered worse by the risk of haemorrhage and consequent detachment, I experimented with a diathermy incision. Such incisions have been employed by the following authors :-

Keysser (1931), Jess (1931), Schmerl (1934), Kawahara (1925) and others.

To determine the optimum site of the incision, my assistant, T. Murayama, and myself experimented, as there is little in the above with a direct bearing on my method of intra-ocular irrigation. 


\title{
Practical Application of Intra-Ocular Irrigation
}

\author{
1. Patients with poor visual acuity whose fundi are invisible \\ from changes in the anterior segment of the eye (Group $A$ ) \\ or elsewhere (Group B).
}

Group A.-Case 3.-(Female aged 18 years.) Partial Staphyloma of the cornea and corneal degeneration. Perception of light before and after the operation.

Employment of my method with 0.9 per cent. salt solution after excision of the staphyloma, revealed a grayish tough, long standing exudate on the posterior surface of the iris. The wound was too small to allow observation of the complete interior of the eye.

Case 5.-(Female aged 14 years.) A shrunken cornea and scleral staphyloma. Requested an artificial eye. No perception of light before or after the operation. Irrigation with salt solution revealed an opaque but normal-sized lens, a fluid vitreous and a grayish globe of exudate $7 \mathrm{~mm}$. in diameter towards the inner side of the posterior chamber. The posterior pole of the vitreous space was normal.

Case 9.-(Male aged 34 years.) Cataract and secondary haemorrhagic glaucoma (r). Perception of light before and after the operation. Extraction of the lens and excision of exudate behind it was followed by venous haemorrhage. 0.9 per cent. salt solution was used.

Case 10.-(Male aged 24 years.) Adherent leucoma with vision of handmovement at $15 \mathrm{c} . \mathrm{m}$. improved to finger counting at the same distance by the intra-ocular irrigation. The iris was adherent to the whole posterior surface of the cornea, which was torn off with iris forceps from behind. The vitreous was normal but the lens absent and the whole retina covered with a light grayish membranous exudate, which was very distinct on the ciliary body. $\quad 0.9$ per cent. salt solution employed.

Case 11.-(Male aged 37 years.) Partial staphyloma of the cornea and secondary glaucoma (e). Vision, handmovement at $15 \mathrm{c.m}$. unaffected by the operation. An exfoliated iris adhered to the posterior corneal surface. The lens was normal and the ciliary body at the nasal side covered with a light grayish exudate looking like a veil, 2 or $3 \mathrm{~mm}$. in diameter. As this could not obstruct vision and removal would have damaged the ciliary body, it was left. 0.9 per cent. salt solution employed.

Case 12.-(Female aged 19 years.) Partial staphyloma of the cornea with perception of light. The lens was atrophic and the interior of the eye free from exudate. Soon after irrigation this patient saw lighter in the eye. Subsequent to the resection of the staphyloma, the eye was tattooed. In this case I employed Ringer's solution.

Case 14.-(Male aged 14 years.) Occlusio pupillae, secondary glaucoma (s). Perception of light. View by intra-ocular irrigation: Lens probably atrophic, being a little smaller than normal. Vitreous clear. Exudate was slightly found on the ciliary body and much more at the nasal part of the posterior pole, inside the eyeball. N.B.-Ringer's solution was used. The patient screwed up the eye, the vitreous and retina were extruded. After stopping the bleeding the operation was terminated. On the 13th day after the operation the cornea was clear and normal in size.

Case 15.-(Male aged 49 years.) A cicatricial trachoma with complete pannus, xerosis corneae, secondary glaucoma and total staphyloma corneae (d). Perception of light. View by intra-ocular irrigation: Lens was normal sized. Entirely turbid cornea touching the iris was seen from the rear side. There was nothing else to describe. N.B.-The same as the last case.

Group B.-Case 1.-(Male aged 22 years.) Adherent leucoma and secondary cataract (s). Finger-counting at $15 \mathrm{c} . \mathrm{m}$. Bleeding was so marked after section of the sclerotic, that it was impossible to observe the interior of the eyeball through the wound or pupil. 0.9 per cent. salt solution was used.

Case 7.-(Male aged 47 years.) Synechia posterior iridis, iridodonesis and aphakia (s). Vision: Hand movement at $15 \mathrm{c.m}$. at first and 0.1 at $0.5 \mathrm{~m}$. 
after the intra-ocular irrigation. View by this operation. There was a mobile grayish capular exudate $(4 \times 3 \mathrm{~mm}$.) with a fine attachment at the ciliary body. A thin rope-like grayish exudate was found on the ciliary body at the nasal side. Both were cut off with scissors. Deep grayish membranous exudate on the posterior surface of the iris was also seen. 0.9 per cent. salt solution was used.

In patients with poor visual acuity whose fundi are invisible from changes in the anterior segment (group A) intra-ocular irrigation will frequently show membranous grayish exudate on both parts of the ciliary body and the posterior surface of the iris dominated on the former. This may be absent from the retina.

Vision may be slightly improved in such cases by means of removal of this exudate and iridectomy from the posterior iridic surface after incision at the limbus. Case 10 is of this type. Moreover in such cases, the lens is absorbed sooner or later. Glaucoma, where no cause in the anterior segment of the eyeball can be found by present methods (case 9 ), may be caused by intraocular bleeding.

In patients with poor visual acuity, whose fundi are invisible and where no pathological changes in the eyeball can be found by present methods (group B) intra-ocular irrigation will show long standing grayish exudate on the ciliary body, the posterior surface of the iris or the retina.

Vision may be slightly improved by incision of the exudate, which is capsular with a long attachment, or linear. For example improvement occurs from hand movement at $15 \mathrm{c} . \mathrm{m}$. to 0.1 at $0.5 \mathrm{~m}$. in case 7 . If, however, the pole of the eyeball on the inside looks grayish from the exudate, recovery of vision is not to be expected.

\section{Application of intra-ocular irrigation in panophthalmitis.-}

Case 4.-(Male aged 23 years.) View by intra-ocular irrigation: Anterior portion of the eye full of cyclitic exudate. I removed a purulent mass from the vitreous. Erythrocyte sedimentation test (Linzenmeier's method), I 25 minutes, II 37 minutes, III 57 minutes before intra-ocular irrigation. During the progress of panophthalmitis, a staphyloma sclerae occurred. Intra-ocular irrigation was performed at this point. 0.9 per cent. salt solution was used and this was followed by autoserum. This operation was repeated with a corneo-scleral flap in a further attempt to prevent progress. Ten days after the operation the tension of the eyeball was reduced to T-2 and after 20 days the eyeball began to atrophy.

Case 6.-(Female aged 44 years.) View by intra-ocular irrigation: exudate in the anterior chamber removed, but lens not seen. Exudate in the vitreous space is quite fluid behind its centre. At the ciliary body the exudate was tough, but I did not touch it as I feared atrophia bulbi. All exudate except that at the ciliary body was removed.

Erythrocyte sedimentation test,

I II III

6, 11, 15 minutes before the operation,

$8,13,21$ minutes on the 3rd day after the operation,

$18,23,29$ minutes on the 10th day after the operation.

The panophthalmitis was caused by ulcus corneae due to pneumococcus. 0.9 per cent. salt solution followed by autoserum was employed. The eye improved for 18 days after the operation, but finally atrophied. 
Case 8.-(Female aged 24 years.) View by intra-ocular irrigation: synechia iridis anterior, marked. An exudate about $1 \mathrm{~mm}$. thick was noticed on the posterior surface of the iris and the ciliary body. As this was old and not due to panophthalmitis, it was left. No lens was found. A capsule 10 c.m. long and $2.5 \mathrm{c} . \mathrm{m}$. wide reached from the purulent mass based at the perforating corneal ulcer to the vitreous space. This flowed out and was excised.

Erythrocyte sedimentation test, I 40 minutes, II 77 minutes, III 145 minutes before the operation. Ulcer was due to the pneumococcus. 0.9 per cent. salt solution and autoserum was used. The case improved from a day following the operation, but after 5 days the patient failed to return.

Case 13.-(Female aged 45 years.) View by intra-ocular irrigation: A light yellowish-gray $5 \times 3 \mathrm{~mm}$. purulent mass found at the posterior surface of a corneal ulcer. The centre of the vitreous was fluid and light yellowish. I did not touch the tough exudate, but removed the purulent mass only.

Erythrocyte sedimentation test,

I II III

2, 9, 11 minutes before trie operation,

$13,20,25$ minutes on the 3rd day after the operation

11, 20, 33 minutes on the 7 th day after the operation.

The eyeball was immobilised by the infiltration around it. After the operation it appeared to improve. As the patient, however, complained greatly of pain, it was enucleated on the 7 th day after the first operation.

This experience shows the possibility of saving cases of panophthalmitis from phthisis bulbi or blindness by intra-ocular irrigation in early stages.

3. Application of this operation for removal of non-magnetic foreign bodies in the eyeball.

Case 2.-(Male aged 22 years.) Vision, 0.1 at $0.5 \mathrm{~m}$. A perforating wound of the cornea $2 \mathrm{~mm}$. long at " 3 o'clock" and another $4 \mathrm{~mm}$. long in the same position in the iris. The radial pattern of the iris was obscured. Some keratic precipitates were present on lower part of the cornea. The pupil was small and irregular and its reaction very much impaired. Grayish exudate was seen in the pupil and behind the lens, which was opaque in the upper nasal quarter. A foreign body in the eyeball was shown by $\mathrm{X}$-ray. It was nonmagnetic in nature. View by intra-ocular irrigation: The posterior surface of the iris was covered by grayish membranous exudate. An exudative mass in the vitreous space was removed by forceps. During the intra-ocular irrigation, a small amount of grayish exudate flowed out.

An especially white mass was seen on the membranous exudate in the lower quarter or wider part of the interior of the eyeball. When I pulled on the mass with forceps the patient complained of pain in the eye. After excision of the mass I found a foreign body at the bottom. The operation was performed under local anaesthesia (5 per cent. cocaine drops).

\section{Conclusion}

In order to avoid damaging intra-ocular tissue as much as possible, I used 0.9 per cent. salt solution or Ringer's solution at body temperature. During irrigation I avoid pressure on the retina and choroid by running the stream of the solution at right angles to the wound from the small opening at the end of the cannula introduced into the vitreous space. By doing this we could observe the interior and remove exudate, purulent masses or foreign bodies from the eyeball under direct vision.

I have called the operating method, here described, "Intraocular irrigation."

Firstly I had to decide how much the tissues were damaged by this operation and which is the better site for the incision, sclerotic 
or limbus. The solutions and technique were tested in experiments with rabbits.

I then had practical experience in 15 human cases.

I will here conclude as a result of my experimental and practical experiences as follows :-

(1) Incision required to be $2 / 5-3 / 5$ around the cornea with conjunctival flap. Only in unavoidable circumstances is the sclerotic to be incised.

(2) Intra-ocular irrigation does not itself cause pathological changes in the eyeball. But, resistance in the cases which in this operation is indicated, is very weak. Therefore we cannot get such good results practically as in experiments with rabbits. Nevertheless, although the cornea may be a little smaller, phthisis bulbi has never been caused by intra-ocular irrigation itself.

(3) Grayish exudate is found especially in the anterior segment of the eyeball and also slightly on the retina, in cases where there are distinct pathological changes in the anterior segment of the eyeball which disturb vision.

Vision hand movement at $15 \mathrm{c} . \mathrm{m}$. improved to finger-counting at the same distance in case 8 .

(4) In a case of cataract with glaucoma, the latter was due to intra-ocular haemorrhage. It was necessary to deal with a good deal of bleeding, during the operation, which may in the worst cases be due to squeezing. On such occasions it is necessary to sew up the wound after controlling the bleeding. If the vitreous is normal, we can observe the inside of the eyeball through the incision, and the operation must not be continued. If nothing gray is observed during the operation we may assume that there are no intra-ocular pathological changes.

(5) Extensive haemorrhage may be caused by scleral incision in cases with poor vision, whose causative changes are not observable in the anterior segment of the eyeball by present methods other than intra-ocular irrigation.

From our experiments with rabbits, we know that this is due to congestion in the eyeball caused by pathological changes. In such cases, corneo-scleral incision with a large conjunctival flap is advisable.

Visual improvement from hand movement at $15 \mathrm{c} . \mathrm{m}$. to 0.1 at $0.5 \mathrm{~m}$. was recorded in a case of slight exudate on the ciliary body and the posterior surface of the iris (case 7).

(6) Panophthalmitis is curable in early stages by intra-ocular irrigation. The case 8 is an example. All symptoms of panophthalmitis including the erythrocyte sedimentation test and except pain improved after intra-ocular irrigation in case 13. Section revealed the pain to be due to subchoroideal haemorrhage.

(7) Intra-ocular irrigation is very useful in the extraction of non-magnetic foreign bodies from the eyeball. 


\section{LITERATURE}

1. T. TutuI.-Intra-ocular washing with Livanol in panophthalmitis. Jikken Ganka Zasshi, Vol. XIX, No. 174, p. 49. January, 1935 (Journal of Practical Ophthalmology).

2. GRUNÉR -Zur Frage der intraokularen Desinfektion. Klin. Monatsbl. f. Augenheilk., Jg. XLIX, S. 532, 1911.

3. K. Комото.-Vitreous washing in bleeding into the vitreous space. Acta Soc. Ophthal. Japonic, Vol. XIV, p. 1C 64,1910

4. S. Miyashita - Vitreous washing. Acta Soc. Ophthal. Japonic., Vol. XVII, p. $1353,1916$.

5. TRUC.-Amputation d s vorderen Bulbusabschnittes: Histologische Untersuchung eines alten Stumpfes. Klin. Monatsbl. f. Augenheilk., Jg. XLII, Bd. 1, S. 598, 1904

6. K. Matsumoto-Cured case of amputatio oculi. Tokio Iji Shinshi, Vol. XXXIII, p. 916, 1905.

7. CEILLIER.- Des differents procédès d'amputation du segment anterieur de l'oeil. Advantages de la suture en bourse et du capitonnage musculaire combinés. Thèse de Bordeaux, 1907. Klin. Monatsbl. f. Augenheilk., Jg. XLVI, S. 332, 1908.

8. Wahlfors.-Ueber Amputatio bulbi. Klin. Monatsbl. f. Augenheilk., Jg. XLIX, S. 532, 1911.

9. Saweljew.-Zur Frage der Transplantation des vordereren Augenabschnittes. Russ. Ophthal.Jl., 1924, Nr. 3; Klin. Monatsbl. f. Augenheilk., Bd. 74, S. 281, 1925.

10. Batalin.-Ein Fall von vollstandiger Hornhaut-transplantation von einem Menschen zum anderen. Nowo-Sibirik. Sibir. Arch. f. Th. U. Kl. Med., Bd. 2, Heft 11-12, 1927; Klin. Monatsbl. f. Augenheilk., Bd. LXXXI, S. 570, 1928.

11. Косн.-Ueber die Mullersche Skleralexzision bei Amotio Retinae. Arch. $f$. Augenheilk., Bd. XCVIII, Heft 1-2, S. 156; Klin. Monatsbl. f. Augenheilk., Bd. LXXIX, S. 138, 1927.

12. Silva.-Chirurgische Technik zur Entfernung der subretinalen Zystizerkus. Rev. de la Assoc. Ned Mexic. Bd. V, Nr. 8, S. 3 ; Klin. Monatsbl. f. Augenheilk., Bd. LXXXI,'S. 744, 1928.

13. Elsching.-Skle alfenster zur Freilegung der Uvea. Klin. Monatsbl. $f$. Augenheilk., Bd. LXXXI. S. 654, 1528 .

14. KREUTZFELDT.-Ueber einen Fall von durch Operation geheilter metastatischer Ophthalmie. Klin. Monatsbl. f. Augenheilk., Bd. LXXXVI, S. 530,1931 .

15. Keusser-Die Elektrochirurgie. Klin. Monatsbl. f. Augenheilk., Bd. LXXXVII, S. 576, 1931

16. JEss.-Elektrochirurgie des Auges und seiner Umgebung. Klin. Monatsbl. f. Augenheilk., Bd. LXXXVII, S. 838, 1931.

17. SCHMERL.-Zur Elektrochirurgie des Auges. Klin. Monatsbl. f. Augenheilk., Bd. LXXXVIII, S. 859, 1932.

18. HildesChaImer.- - Heilung von Sekundarglaukom durch Skleralexzision mit dem elektrischen Messer. Klin. Monatsbl. $f$. Augenheilk., Bd. XC, S. 399, 1935.

19. T. Tutui.-Ophthalmological application of surgical diathermy. Jiryo Oyobi Shoho (Medical treatment and prescription), Vol XIV, No. 8, September, 1933.

20. LUTHER and PETER.-Technic of electrocoagulation in the treatment of retinal detachment. Amer. Jl. of Ophthal., Vol. XVII, No. 10, p. 924, October, 1934.

21. S. KAWARA.- Experimental studies of eye changes from a polycyclic electric current (3 parts). Changes of the retina and choroid. Acta Soc. Ophthal. Japonic., Vol. XXXIX, No. 11, p. 2171, 1935. 